in vivo $34: 3093-3101(2020)$

doi:10.21873/invivo.12142

Review

\title{
Telomere Length and Hematological Disorders: A Review
}

\author{
BEATRIZ MARIA DIAS NOGUEIRA*, CAIO BEZERRA MACHADO*, RAQUEL CARVALHO MONTENEGRO, \\ MARIA ELISABETE AMARAL DE MORAES and CAROLINE AQUINO MOREIRA-NUNES \\ Pharmacogenetics Laboratory, Drug Research and Development Center (NPDM), \\ Department of Physiology and Pharmacology, Federal University of Ceará, Fortaleza, CE, Brazil
}

\begin{abstract}
Telomeres compose the end portions of human chromosomes, and their main function is to protect the genome. In hematological disorders, telomeres are shortened, predisposing to genetic instability that may cause DNA damage and chromosomal rearrangements, inducing a poor clinical outcome. Studies from 2010 to 2019 were compiled and experimental studies using samples of patients diagnosed with hematological malignancies that reported the size of the telomeres were described. Abnormal telomere shortening is described in cancer, but in hematological neoplasms, telomeres are still shortened even after telomerase reactivation. In this study, we compared the sizes of telomeres in leukemias, myelodysplastic syndrome and lymphomas, identifying that the smallest telomeres are present in patients at relapse. In conclusion, the experimental and clinical data analyzed in this review demonstrate that excessive telomere shortening is present in major hematological malignancies and its analysis and measurement is a crucial step in determining patient prognosis, predicting disease risk and assisting in the decision for targeted therapeutic strategies.
\end{abstract}

The word telomere originates from the Greek words $\tau \dot{\varepsilon} \lambda o \varsigma$ (telos, end, extremity)+ $\mu \varepsilon \dot{\varrho} \varrho \varsigma$ (meros, part), meaning "part of the extremity". The telomeres compose the end portions of chromosomes and consist of many 5'-TTAGGG-3' noncoding repeats (1).

This article is freely accessible online.

*These Authors contributed equally to this work.

Correspondence to: Caroline Aquino Moreira-Nunes, Federal University of Ceará, Coronel Nunes de Melo st, n 1000, Rodolfo Teófilo, CEP: 60430-275 Fortaleza, CE, Brazil. Tel: +55 8533668033,e-mail: carolfam@gmail.com

Key Words: Telomere length, cancer, hematological disorders, review.
During a normal lifespan, telomeres naturally shorten. However, this can become a problem when excessive telomere shortening is observed in stem cells of both pediatric and adult patients. Healthy cells are predisposed to a division limit, also known as Hayflick limit, of 50 to 70 divisions before the cell undergoes senesce or apoptosis due to telomere attrition $(2,3)$.

Short telomeres are associated with genetic instability, which may characterize them as a predisposition factor for hematological malignancies $(4,5)$.

\section{Human Telomeres and their Functions}

Human telomeres are the end portions of chromosomes, which act primarily in DNA protection and genomic stability, preventing fusions and damage to the genetic material. Telomeres are composed of approximately 1000 to 2000 base pairs or 5-12 kb of non-coding TTAGGG repeats, which interacts with a group of proteins denominated as Shelterin complex (Figure 1) (3, 6-8).

A major characteristic of telomeres is their progressive shortening that happens naturally with each division of somatic cells. The shortening occurs due to the DNA end replication problem, which consists of the inability of the cellular machinery to effectively synthesize the chromosomes ends during replication, alongside with the lack or insufficiency of pathways that promote telomere elongation, such as telomerase activity or the alternative lengthening of telomeres (ALT) (9-11).

Telomere elongation occurs primarily by human telomerase (hTERT) activity, which is a ribonucleoprotein enzyme specialized in neutralizing telomeric DNA attrition by synthesizing new TTAGGG repeats at chromosome ends. This enzyme is composed by two subunits; the catalytic domain is the telomerase reverse transcriptase (TERT), which utilizes the telomerase messenger RNA (TERC) subunit as a complementary template for the addition of nucleic acids to the telomere. The replicative immortality in most tumors is associated with a loss of homeostasis in the telomere- 


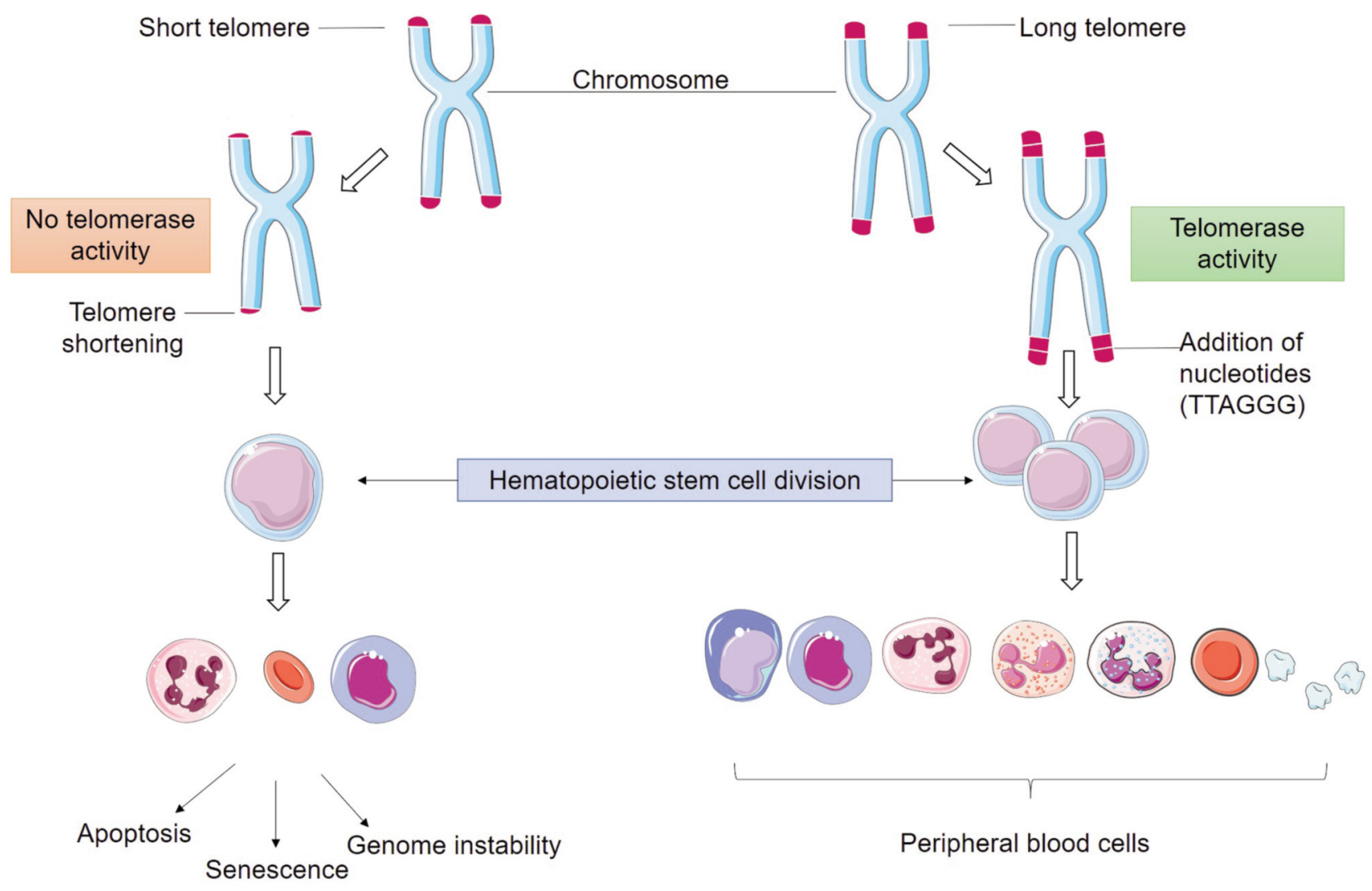

Figure 1. Hematopoietic stem cells express intrinsic telomerase activity which is required to sustain their accelerated replication cycle. When telomerase activity is lacking hematopoietic stem cells become unstable, leading to DNA damage and consequent bone marrow failure (5).

telomerase complex, being characterized by telomere elongation and in $90 \%$ of the cases it is due to the reactivation of telomerase enzyme (Figure 2) (12-14).

\section{Telomere and Telomerase in Human Cancer}

Cells with malignant potential can adapt and escape replicative senescence, by suppressing DNA damage response mechanisms or by over-activating telomere maintenance pathways, such as telomerase activity, and thus acquiring immortality and initiating the tumorigenesis process (15).

Dysfunctions affecting the telomere complex might expose the DNA to enzymatic degradation leading to breaks, deletions, fusions and accumulation of DNA mutations. The consequence of this genomic instability is cancer progression and a worse prognosis for the afflicted patients $(16,17)$.

The risk for cancer development aggravates in relation to the decrease in telomere length (TL) and after the disease is consolidated the telomeres tend to elongate once again. This observation shows that critically shortened and dysfunctional telomeres contribute to genetic instability and oncogenesis $(1,17,18)$.

\section{Telomeres in Hematopoietic Dysfunction}

The lifespan of mature hematopoietic cells is very limited, demanding their constant production and replacement by the bone marrow. It is expected that hematopoietic cells replicate 50 to 200 times before proceeding to replicative senescence (19).

The telomere attrition in stem cell is accelerated during an individual's early years of life, when one stem cell will replicate from 15 to 30 times. During the adult life, between 50 and 60 years, telomere shortening progresses more slowly, however, after this period it accelerates once again. In $\mathrm{T}$ lymphocytes 33 base pairs of telomeric sequence are usually lost every year, while B lymphocytes only lose around 15 base pairs a year $(19,20)$.

Mature hematopoietic cells derive from the proliferation of hematopoietic stem and progenitor cells (HSPC). The stem cells are capable of auto-renewal and production of other stem cells, however, this renewal will only occur when these cells are near senescence and in need of replacement. Usually, the telomeres of stem cells shorten over the years, but when this shortening is excessive it may lead to bone 


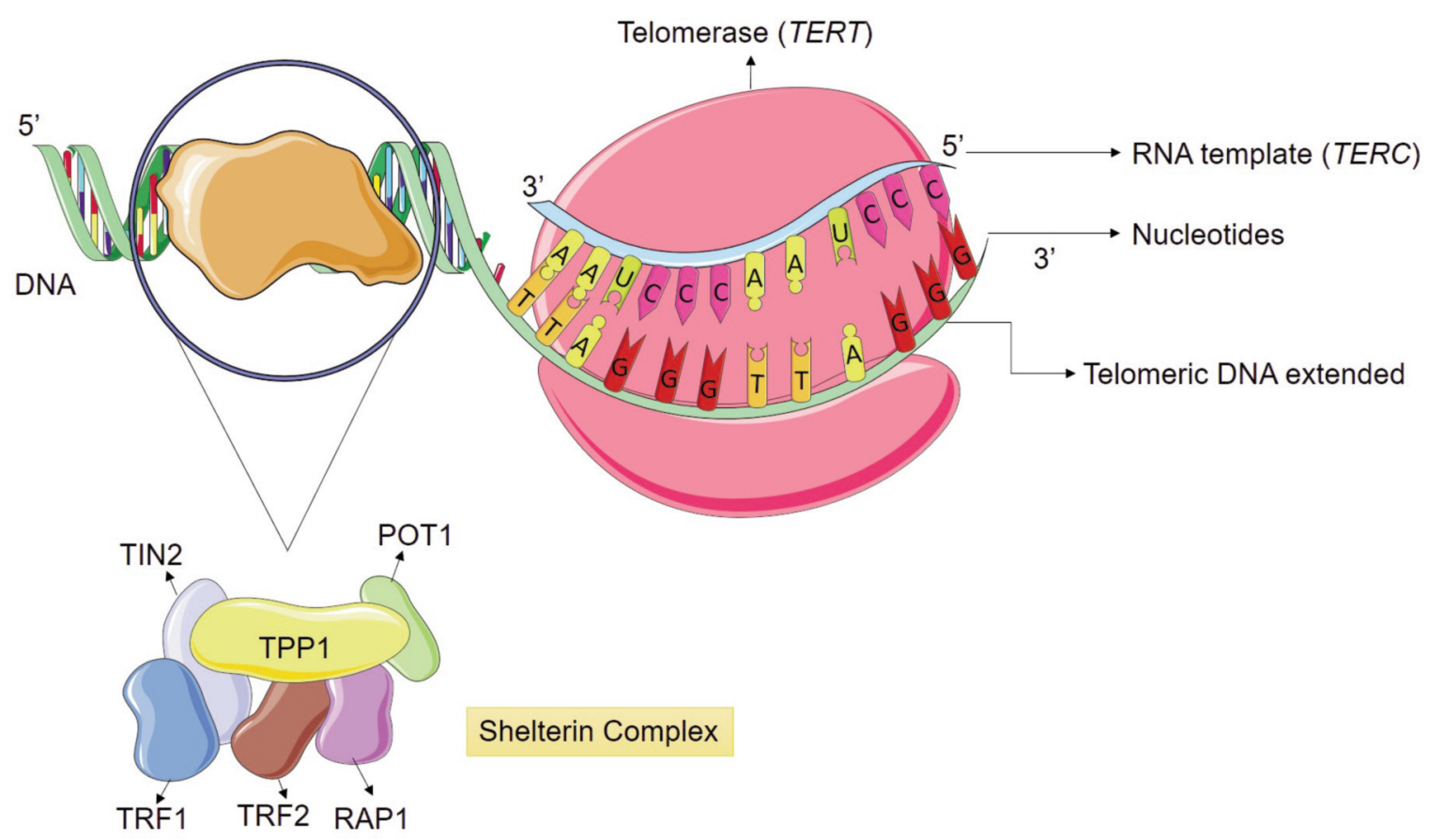

Figure 2. Telomerase enzyme counteracts nucleotide loss during cell replication. The catalytic domain has telomerase reverse transcriptase (TERT) activity, which utilizes the telomerase mRNA (TERC) subunit as a complementary template for the addition of nucleotides to telomeric DNA. The Shelterin complex is composed of six proteins (POT1, TPP1, TRF1, TRF2, TIN2 and Rap1) responsible for maintaining genetic integrity, assisting in the prevention of excessive DNA damage and regulating telomere-telomerase interaction. The complex protects telomeric DNA from unwanted degradation and chromosomal fusions (13).

marrow insufficiency and failure, predisposing stem cells to malignancy $(19,21,22)$.

Although the standard model of oncogenesis for the majority of cancers predicts the presence of telomerase overexpression and consequent telomere elongation, some cancer subtypes are able to maintain an indefinite proliferation by expressing telomerase but not necessarily elongating the telomeres, as is the case of hematological neoplasms $(1,10$, $23,24)$.

\section{Hematological Malignancies}

Most hematological neoplasms possess an uncertain etiology, however, there are some predisposing factors. Malignant transformations initiate due to complex interactions between genetic factors such as chromosomal rearrangements, aneuploidies, punctual mutations, deletions, insertions, duplications and amplifications. Among them, chromosomal translocations and aneuploidies are the main biomarkers for genetic instability and development of hematological malignancies $(25,26)$.

The dysfunctional shortening of telomeres may be present in congenital anemias, as in Fanconi anemia or Shwachman Diamond syndrome, but disease progression and telomere shortening do not have a strong association. However, telomere shortening alongside chromosomal mutations and telomerase reactivation may be predisposing factors for the development of hematological neoplasms such as myelodysplastic syndrome and leukemias $(5,27)$.

Hematological disorders usually present similar clinical signs amongst each other, making an early differential diagnosis necessary. The occurrence of telomere shortening in hematological malignancies is associated with major genomic rearrangements and DNA damage that is not detected in cells with longer telomeres. This observation leads to the understanding that the study and analyses of TL is of utmost importance for a better prognosis of patients in the clinical practice $(15,28)$.

\section{Telomere Length and Hematological malignancies}

Table I presents studies relating telomere length and prognosis of patients afflicted by hematological malignancies.

Myelodysplastic syndromes (MDS) are a heterogeneous group of clonal diseases that are characterized by an ineffective hematopoiesis consequentially leading to cytopenia and dysplasia in the peripheral blood. MDS patients express a progressive shortening of the telomeres which leads to 
Table I. Cytogenetics and prognosis associated with shorter telomeres at diagnosis of hematological malignancies.

\begin{tabular}{|c|c|c|c|c|c|c|}
\hline $\begin{array}{l}\text { Leukemia } \\
\text { subtype }\end{array}$ & $\begin{array}{l}\text { Telomere } \\
\text { length }\end{array}$ & $\begin{array}{l}\text { Associated } \\
\text { cytogenetics }\end{array}$ & $\begin{array}{l}\text { Clinical } \\
\text { features }\end{array}$ & $\begin{array}{l}\text { Drug } \\
\text { treatment }\end{array}$ & $\begin{array}{l}\text { Prognostic } \\
\text { significance }\end{array}$ & Reference \\
\hline CLL & $\sim 3.37 \mathrm{~kb}$ & $\begin{array}{l}\text { Unmutated IGHV; } \\
\text { TP53 mutation; } \\
\text { SF3BI mutation }\end{array}$ & $\begin{array}{l}\text { Higher WBC count; } \\
\text { Higher serum } \\
\text { thymidine kinase } \\
\text { activity; Binet } \\
\text { stage B }\end{array}$ & $\begin{array}{l}\text { Fludarabine, } \\
\text { cyclophosphamide } \\
\text { and rituximab }\end{array}$ & $\begin{array}{l}\text { Significantly } \\
\text { shorter PFS } \\
\text { and OS }\end{array}$ & $\begin{array}{c}\text { Jebaraj et al., } \\
2019 \text { (29) }\end{array}$ \\
\hline CLL & N.I & $\begin{array}{c}\text { CD38 positivity; } \\
\text { Elevated } \beta 2 \mathrm{M} ; \\
\text { Unmutated IGHV; } \\
\text { High-risk cytogenetic } \\
\text { lesions }\end{array}$ & - & $\begin{array}{l}\text { Fludarabine, } \\
\text { cyclophosphamide } \\
\text { and rituximab }\end{array}$ & $\begin{array}{l}\text { Significantly } \\
\text { shorter PFS } \\
\text { and reduced OS }\end{array}$ & $\begin{array}{l}\text { Norris et al., } \\
2019 \text { (30) }\end{array}$ \\
\hline AML/MDS & $\begin{array}{l}\sim 0.42 \mathrm{~T} / \mathrm{S} \\
\quad \text { ratio }\end{array}$ & - & - & $\begin{array}{l}\text { Anthracycline } \\
\text { combined with } \\
\text { cytosine arabinoside; } \\
\text { 5-azacytidine }\end{array}$ & $\begin{array}{l}\text { No association } \\
\text { between TL } \\
\text { and OS or risk } \\
\text { of relapse }\end{array}$ & $\begin{array}{l}\text { Warny et al., } \\
2018 \text { (31) }\end{array}$ \\
\hline CML & 25 to 75 a.u. & $\begin{array}{c}\text { Increased BCR-ABL } \\
\text { expression }\end{array}$ & $\begin{array}{l}\text { Increased leukemic } \\
\text { clonal size }\end{array}$ & - & - & $\begin{array}{l}\text { Bouillon et al., } \\
\quad 2018 \text { (32) }\end{array}$ \\
\hline CLL & $\sim 3.28 \mathrm{~kb}$ & $\begin{array}{l}\text { TP53 mutation } \\
\text { in treatment-naive } \\
17 \mathrm{p} \text { - patients }\end{array}$ & $\begin{array}{l}\text { Higher serum } \\
\text { thymidine kinase } \\
\text { activity and increased } \\
\text { chromothripsis rates } \\
\text { in } 17 \text { p- patients with } \\
\text { no prior treatment }\end{array}$ & $\begin{array}{l}\text { Alemtuzumab } \\
\text { and } \\
\text { dexamethasone }\end{array}$ & $\begin{array}{l}\text { Shorter PFS } \\
\text { and OS in CLL } \\
\text { refractory to prior } \\
\text { chemotherapy }\end{array}$ & $\begin{array}{l}\text { Steinbrecher } \\
\text { et al., } \\
2017(33)\end{array}$ \\
\hline CLL & N.I & $\begin{array}{l}\text { Complex karyotype; } \\
\text { TP53 mutation }\end{array}$ & - & - & - & $\begin{array}{c}\text { Thomay et al., } \\
2017 \text { (34) }\end{array}$ \\
\hline AML/MDS & $\leq 3.81 \mathrm{~kb}$ & $\begin{array}{l}\text { FLT3-ITD mutation } \\
\text { in AML cohort }\end{array}$ & $\begin{array}{c}\text { Cytopenia in MDS } \\
\text { cohort }\end{array}$ & - & $\begin{array}{l}\text { Worse OS in } \\
\text { MDS cohort }\end{array}$ & $\begin{array}{l}\text { Williams et al., } \\
2017 \text { (35) }\end{array}$ \\
\hline MDS & N.I & $\begin{array}{c}\text { No association } \\
\text { between TL and } \\
\text { cytogenetic abnormalities }\end{array}$ & - & - & Shorter OS & $\begin{array}{l}\text { Park et al., } \\
2017 \text { (36) }\end{array}$ \\
\hline AML & $\sim 5.22 \mathrm{~kb}$ & $\begin{array}{l}\text { FLT3-ITD/TKD } \\
\text { mutations; KIT and } \\
\text { NRAS mutations }\end{array}$ & - & - & $\begin{array}{l}\text { Decreased OS } \\
\text { at } 6 \text { months }\end{array}$ & $\begin{array}{l}\text { Watts et al., } \\
2016 \text { (37) }\end{array}$ \\
\hline AML & $\begin{array}{c}0.43 \text { to } 0.59 \\
\text { TC }\end{array}$ & FLT3-ITD & 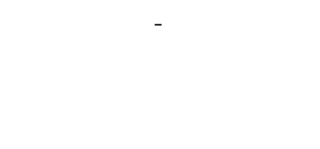 & $\begin{array}{l}\text { Gemtuzumab } \\
\text { Ozogamicin; } \\
\text { Conventional } \\
\text { chemotherapy }\end{array}$ & $\begin{array}{l}\text { Delayed recovery } \\
\text { of neutrophil } \\
\text { count after } \\
\text { chemotherapy }\end{array}$ & $\begin{array}{l}\text { Gerbing et al., } \\
2016 \text { (38) }\end{array}$ \\
\hline APL & $\sim 5.1 \mathrm{~kb}$ & - & $\begin{array}{l}\text { Higher WBC } \\
\text { count }\end{array}$ & $\begin{array}{c}\text { ATRA; Cytosine } \\
\text { arabinoside; Daunorubicin; } \\
\text { ATO; Mercaptopurine; } \\
\text { Methotrexate; } \\
\text { Gemtuzumab ozogamicin }\end{array}$ & $\begin{array}{l}\text { Decreased } \\
\text { DFS and OS }\end{array}$ & $\begin{array}{l}\text { Baljevic et al., } \\
2016(39)\end{array}$ \\
\hline CLL & N.I & $\begin{array}{l}\text { High risk aberrations; } \\
\text { Deletion of } 11 \mathrm{q} 22-23 \text { or } \\
\text { 17p13; Increased occurrence } \\
\text { of uniparental disomy }\end{array}$ & e & - & - & $\begin{array}{l}\text { Sellmann et al., } \\
2016(40)\end{array}$ \\
\hline HCL/HCLv & $\begin{array}{l}\sim 0.47 \mathrm{~T} / \mathrm{S} \\
\text { ratio in } \mathrm{HCL} ; \\
\sim 0.40 \mathrm{~T} / \mathrm{S} \text { ratio } \\
\quad \text { in HCLV }\end{array}$ & Unmutated IGHV & Older age & - & Shorter OS & $\begin{array}{l}\text { Arons et al., } \\
2015 \text { (41) }\end{array}$ \\
\hline CLL & $\sim 2.26 \mathrm{~kb}$ & - & - & S & $\begin{array}{l}\text { Significantly shorter } \\
\text { OS regardless of } \\
\text { other prognostic } \\
\text { markers status }\end{array}$ & $\begin{array}{l}\text { Lin et al., } \\
2014(42)\end{array}$ \\
\hline MCL & $\sim 4.3 \mathrm{~kb}$ & $\begin{array}{l}\text { No relation was } \\
\text { identified regarding } \\
\text { TL andcytogenetic } \\
\text { abnormalities }\end{array}$ & $\begin{array}{c}\text { No association } \\
\text { between TL and lactate } \\
\text { dehydrogenase levels, } \\
\text { WBC count or MIPI groups }\end{array}$ & s & $\begin{array}{c}\text { No significant } \\
\text { difference in OS or } \\
\text { PFS was identified }\end{array}$ & $\begin{array}{l}\text { Jebaraj et al., } \\
2013 \text { (43) }\end{array}$ \\
\hline
\end{tabular}


Table I. Continued

\begin{tabular}{|c|c|c|c|c|c|c|}
\hline $\begin{array}{l}\text { Leukemia } \\
\text { subtype }\end{array}$ & $\begin{array}{l}\text { Telomere } \\
\text { length }\end{array}$ & $\begin{array}{l}\text { Associated } \\
\text { cytogenetics }\end{array}$ & $\begin{array}{l}\text { Clinical } \\
\text { features }\end{array}$ & $\begin{array}{l}\text { Drug } \\
\text { treatment }\end{array}$ & $\begin{array}{l}\text { Prognostic } \\
\text { significance }\end{array}$ & Reference \\
\hline CLL & N.I & $\begin{array}{l}\text { Unmutated IGHV; } \\
\text { TP53 mutation; } \\
\text { Deletion of } 17 \mathrm{p} 13 \\
\text { and } 11 \mathrm{q} 22-\mathrm{q} 23\end{array}$ & - & - & - & $\begin{array}{c}\text { Jebaraj et al., } \\
2013(43)\end{array}$ \\
\hline CLL & N.I & $\begin{array}{l}\text { Unmutated IGHV; } \\
\text { CD38 positivity; } \\
\text { 11q/17p deletion; } \\
\text { Mutated NOTCH1 and } \\
\text { SF3B1; Increased } \\
\text { copy-number aberrations }\end{array}$ & - & - & $\begin{array}{l}\text { Short time to } \\
\text { treatment and OS }\end{array}$ & $\begin{array}{c}\text { Mansouri et al., } \\
2013 \text { (44) }\end{array}$ \\
\hline CLL & $\sim 4.85 \mathrm{~kb}$ & $\begin{array}{c}\text { Unmutated IGHV; } \\
\text { High CD38 expression; } \\
11 \mathrm{q} \text { and } 17 \mathrm{q} \text { deletion; } \\
12 \text { trisomy }\end{array}$ & $\begin{array}{l}\text { High hTERT } \\
\text { expression }\end{array}$ & - & $\begin{array}{c}\text { Decreased } \\
\text { lymphocyte doubling } \\
\text { time; Shorter time to } \\
\text { first treatment when } \\
\text { associated with high } \\
\text { hTERT levels }\end{array}$ & $\begin{array}{l}\text { Rampazzo et al., } \\
2012(45)\end{array}$ \\
\hline CLL & $\begin{aligned} & \Delta \mathrm{TL} \\
&<-4.2 \mathrm{~kb}\end{aligned}$ & $\begin{array}{l}\text { Unmutated IGHV; } \\
\text { Deletion of } 11 \mathrm{q} 22 \\
\text { or } 17 \mathrm{p} 13\end{array}$ & $\begin{array}{l}\text { Increased } \\
\text { telomerase } \\
\text { activity }\end{array}$ & - & $\begin{array}{l}\text { Worse PFS and OS } \\
\text { when analyzed } \\
\text { alongside unmutated } \\
\text { IGHV status }\end{array}$ & $\begin{array}{l}\text { Sellmann et al., } \\
2011 \text { (46) }\end{array}$ \\
\hline CLL & N.I & $\begin{array}{l}\text { Increased ZAP-70, } \\
\text { CD38 and } \beta 2 \mathrm{M} \text { expression; } \\
\text { Increased VH gene } \\
\text { sequence homology }\end{array}$ & Binet stage $\mathrm{C}$ & - & $\begin{array}{l}\text { Disease progression } \\
\text { and poor prognosis }\end{array}$ & $\begin{array}{l}\text { Lin et al., } \\
2010(47)\end{array}$ \\
\hline
\end{tabular}

N.I: Not informed; ALL: acute lymphoblastic leukemia; AML: acute myeloid leucemia; CLL: chronic lymphoblastic leukemia; CML: chronic myeloid leukemia; MDS: myelodysplastic syndrome; MCL: mantle cell lymphoma; HCV: hairy cell ceukemia; HCLV: hairy cell leukemia variant; APL: acute promyelocytic leukemia; WBC: white blood cell; kb: kilobases; T/S: ratio telomere repeat copy numbers (T) and single gene copy numbers (S); a.u: arbitrary fluorescent unit; OS: overall survivor; TC: telomere content.

persistent physiological damage to the DNA and other classical MDS characteristics, demonstrating a correlation between TL, MDS pathophysiology and progression to malignancy as acute myeloid leukemia $(15,21,48,49)$.

Leukemias are malignant disorders characterized by increased numbers of white blood cells in the peripheral blood or bone marrow. In chronic leukemias there is usually a prevalence of defective mature cells that may have a myeloid origin, as in chronic myeloid leukemia (CML), or a lymphoid origin, as in chronic lymphoid leukemia (CLL). On the other hand, in acute leukemias there is a predominance of blastic cells, being determined as acute myeloid leukemia (AML) or acute lymphoid leukemia (ALL) (50).

Amongst acute leukemias, ALL patients express shorter telomeres than AML patients, however, as the diseases progress, AML telomeres tend to shorten in an increased pace compared to ALL telomeres. ALL expressing a malignant phenotype for B lymphocytes present shorter telomeres than those from AML $(41,51,52)$.

CML usually originates from a reciprocal translocation between chromosome 9 and chromosome 22, creating the Philadelphia chromosome $(\mathrm{Ph}+)$ and the chimeric gene $B C R$ -
$A B L$. Telomeres are shorter in CML during the accelerated phase and blast crisis when compared to the chronic phase. Moreover, in patients afflicted by CLL, there is an association between shorter telomeres and an unfavorable prognosis $(15,41,52-54)$.

\section{Telomere Length Studies}

The most common neoplasms related to shorter telomeres and age are MDS and AML (49). Patients with short telomeres present a greater risk for developing MDS, even though only a minor percentage actually does $(36,49)$.

The TL of patients afflicted by AML and those with a high risk for MDS were analyzed simultaneously; in both cases TL was similar $(31,35)$. In a study by Warny et al., TL was analyzed in three stages, the first was at disease diagnosis, the second was during treatment, where telomere elongation was already observed, and the third at patient relapse when it was estimated that TL was shorter than at the time of diagnosis (31).

Patients diagnosed with AML have shown a notable shortening of telomeres and those with longer telomeres present an increased overall survival at 6-month period 
compared to those with shorter telomeres $(37,38)$. Patients with complex cytogenetics tend to express shorter telomeres in comparison to those with a normal karyotype. The TL also changes in comparison to treatment outset and complete remission, showing an elongation pattern in the bone marrow cells from patients at treatment completion, when compared to normal cells (55).

Acute Promyelocytic Leukemia (APL) is an AML subtype presenting an incidence of 10 to $15 \%$ of AML cases (56). Telomeres in APL patients are shorter in comparison to healthy controls and their length is comparable to that of patients afflicted by regular AML. Patients in complete remission from APL demonstrate considerable telomere elongation, suggesting that TL is a predictive marker for patient prognosis (39).

In regard to patients diagnosed with ALL presenting complex karyotypes, the telomeres are shorter than those of patients harboring normal karyotypes (55). It has also been observed that adult patients diagnosed with ALL have short telomeres, indicating aggressive disease $(51,55)$.

In CLL, telomeres are shorter in B lymphocytes lineages than in $\mathrm{T}$ lymphocytes and these shorter telomeres are also associated with chromosomal aberrations $(44,45)$. In a study conducted by Steinbrecher et al., shorter telomeres were observed in CLL patients compared to controls, and $83 \%$ of the analyzed patients had telomeres shorter than the average (33).

Defining the TL in CLL might help predict the disease risk and propose a specific therapeutic course for patients, as shorter telomeres have a strong association with an inferior progression free survival (PFS) and disease aggressiveness (29, 30, 34, 40, 42, 46, 47, 57, 58).

Mantle cell lymphoma (MCL) is an aggressive lymphoma subtype, representing only $4 \%$ of lymphoma cases (59). In a study conducted by Jebaraji et al., TL in MCL cells was not significantly associated with chromosomal aberrations, while CLL patients harboring complex karyotypes had a strong association with shorter telomeres, suggesting that the increase in aberration incidence was a consequence of genomic instability caused by telomere attrition (43).

Hairy cell leukemia (HCL) is a mature B lymphocyte leukemia, which presents a distinct immunophenotype and is classified in two subgroups: the classic HCL and HCL variant (HCL-v) (60). In a study conducted by Arons et al., it was shown that patients afflicted by HCL had longer telomeres than those afflicted by HCL-v, suggesting that the poorer prognosis associated with HCL-v might be due to increased telomere attrition (41). Furthermore, in a study by Walsh et al., TL was found to be longer in classic HCL patients than in those diagnosed with CLL (61).

Ohyashiki et al., observed that individuals diagnosed with CML had shorter telomeres in comparison to healthy controls, increased predisposition to developing blast crises as well as greater disease severity during the chronic phase.
Patients undergoing blastic phase presented shorter TL than expected by their age and also when compared to chronic phase patients (62). Caocci et al., suggested that telomere shortening in CML cases happens before Philadelphia chromosome origination, and influences chromosomal instability and disease progression (63).

Bouillon et al., found that telomeres of CML patients were shorter in leukemic stem cells than in hematopoietic stem cells. Furthermore, leukemic cells can alter normal hematopoietic cells through extrinsic pathways that impact in the differentiation and auto-renewal cellular capacity, also altering the TL of hematopoietic cells. This study suggested that non-leukemic cells may already present a deficit in TL that would contribute to disease onset and progression (32).

Telomere homeostasis disorders have been heavily associated with leukemogenesis and neoplasm treatment, especially when these disorders induce telomere attrition. The "telomere crises" influences resistance to chemotherapy as their shortening might induce karyotype complexity and malignant cell adaptation, allowing their increased proliferation to overcome treatment cytotoxicity $(42,43,47,64,65)$.

\section{Conclusion}

Experimental and clinical data analyzed in this review demonstrate that excessive telomere shortening is present in major hematological malignancies and its analyses and measurement is a crucial step in determining patient prognosis, predicting disease risk and assisting in the decision for targeted therapeutic strategies.

\section{Conflicts of Interest}

The Authors declare no conflicts of interest regarding this study.

\section{Authors' Contributions}

Nogueira BMD, Machado CB and Moreira-Nunes CA designed the study; Nogueira BMD, Machado $\mathrm{CB}$ and Moreira-Nunes CA prepared the figures; Nogueira BMD, Machado CB, Montenegro RC, Moraes MEA and Moreira-Nunes CA wrote the article; Nogueira BMD, Machado CB and Moreira-Nunes CA revised the final version. All Authors read and approved the final article.

\section{Acknowledgements}

This study was supported by Brazilian funding agencies National Counsel of Technological and Scientific Development (CNPq; to RCM, MEAM and CAMN).

\section{References}

1 Herrmann M, Pusceddu I, März W and Herrmann W: Telomere biology and age-related diseases. Clin Che Lab Med 56: 12101222, 2018. PMID: 29494336. DOI: 10.1515/cclm-2017-0870 
2 Marcon F, Siniscalchi E, Crebelli R, Saieva C, Sera F, Fortini P, Simonelli V and Palli D: Diet-related telomere shortening and chromosome stability. Mutagenesis 27: 49-57, 2011. PMID: 21857007. DOI: 10.1093/mutage/ger056

3 Wu L, Fidan K, Um JY and Ahn KS: Telomerase: Key regulator of inflammation and cancer. Pharmacol Res 155: 104726, 2020. PMID: 32109579. DOI: 10.1016/j.phrs.2020.104726

4 Werner B, Beier F, Hummel S, Balabanov S, Lassay L, Orlikowsky T, Dingli D, Brümmendorf TH and Traulsen A: Reconstructing the in vivo dynamics of hematopoietic stem cells from telomere length distributions. eLife 4: 2015. PMID: 26468615. DOI: 10.7554/elife.08687

5 Paiva RM and Calado RT: Telomere dysfunction and hematologic disorders. Prog Mol Biol Transl Sci 125: 133-157, 2014. PMID: 24993701. DOI: 10.1016/b978-0-12-3978981.00006-2

6 Gancarcíková M, Zemanová Z, Brezinová J, Berková A, Vcelíková S, Smigová J and Michalová K: The role of telomeres and telomerase complex in haematological neoplasia: The length of telomeres as a marker of carcinogenesis and prognosis of disease. Prague Med Rep 111: 91-105, 2010. PMID: 20653999.

7 Shay JW and Wright WE: Telomeres and telomerase: Three decades of progress. Nat Rev Genet 20: 299-309, 2019. PMID: 30760854. DOI: 10.1038/s41576-019-0099-1

8 Ram R, Uziel O and Lahav M: The importance of the telomere and telomerase system in hematological malignancies. Leukemia Lymphoma 46: 1121-1135, 2005. PMID: 16085552. DOI: $10.1080 / 10428190500125853$

9 Yuan X, Dai M and Xu D: Telomere-related markers for cancer. Curr Top Med Chem 20: 410-432, 2020. PMID: 31903880. DOI: $10.2174 / 1568026620666200106145340$

10 Roake CM and Artandi SE: Regulation of human telomerase in homeostasis and disease. Nat Rev Mol Cell Biol 21: 384-397, 2020. PMID: 32242127. DOI: 10.1038/s41580-020-0234-z

11 Wellinger and Raymund J: In the end, what's the problem? Mol Cell 53: 855-856, 2014. PMID: 24656125. DOI: 10.1016/j. molcel.2014.03.008

12 Lee DD, Leão R, Komosa M, Gallo M, Zhang CH, Lipman T, Remke M, Heidari A, Nunes NM, Apolónio JD, Price AJ, Mello RAD, Dias JS, Huntsman D, Hermanns T, Wild PJ, Vanner R, Zadeh G, Karamchandani J, Das S, Taylor MD, Hawkins CE, Wasserman JD, Figueiredo A, Hamilton RJ, Minden MD, Wani K, Diplas B, Yan H, Aldape K, Akbari MR, Danesh A, Pugh TJ, Dirks PB, Castelo-Branco $\mathrm{P}$ and Tabori U: DNA hypermethylation within TERT promoter upregulates TERT expression in cancer. J Clin Invest 129: 223-229, 2018. PMID: 30932912. DOI: 10.1172/jci121303

13 Smith EM, Pendlebury DF and Nandakumar J: Structural biology of telomeres and telomerase. Cell Mol Life Sci 77: 6179, 2019. PMID: 31728577. DOI: 10.1007/s00018-019-03369-x

14 Rubtsova $\mathrm{M}$ and Dontsova O: Human telomerase RNA: Telomerase component or more?" Biomolecules 10: 873, 2020. PMID: 32517215. DOI: 10.3390/biom10060873

15 Vasko T, Kaifie A, Stope M, Kraus T and Ziegler P: Telomeres and telomerase in hematopoietic dysfunction: prognostic implications and pharmacological interventions. Int J Mol Sci 18: 2267, 2017. PMID: 29143804. DOI: 10.3390/ijms18112267

16 Fiorini E, Santoni A and Colla S: Dysfunctional telomeres and hematological disorders. Differentiation 100: 1-11, 2018. PMID: 29331736. DOI: 10.1016/j.diff.2018.01.001
17 M'Kacher R, Colicchio B, Borie C, Junker S, Marquet V, Heidingsfelder L, Soehnlen K, Najar W, Hempel WM, Oudrhiri $\mathrm{N}$, Wilhelm-Murer N, Miguet M, Arnoux M, Ferrapie C, Kerbrat W, Plesch A, Dieterlen A, Girinsky T, Voisin P, Deschenes G, Tabet A-C, Yardin C, Bennaceur-Griscelli A, Fenech M, Carde $\mathrm{P}$ and Jeandidier E: Telomere and centromere staining followed by M-FISH improves diagnosis of chromosomal instability and its clinical utility. Genes 11: 475, 2020. PMID: 32349350. DOI: $10.3390 /$ genes 11050475

18 Sheng X, Tong N, Tao G, Luo D, Wang M, Fang Y, Li J, Xu M, Zhang $\mathrm{Z}$ and Wu D: TERT polymorphisms modify the risk of acute lymphoblastic leukemia in Chinese children. Carcinogenesis 34: 228-235, 2012. PMID: 23066086. DOI: $10.1093 /$ arcin/bgs 325

19 Allegra A, Innao V, Penna G, Gerace D, Allegra AG and Musolino C: Telomerase and telomere biology in hematological diseases: A new therapeutic target. Leukemia Res 56: 60-74, 2017. PMID: 28196338. DOI: 10.1016/j.leukres.2017.02.002

20 Gadalla SM and Savage SA: Telomere biology in hematopoiesis and stem cell transplantation. Blood Rev 25: 261-269, 2011 PMID: 21764192. DOI: 10.1016/j.blre.2011.06.004

21 Lansdorp PM: Maintenance of telomere length in AML. Blood Adv 1: 2467-2472, 2017. PMID: 29296896. DOI: 10.1182/ bloodadvances.2017012112

22 Ju Z, Zhang J, Gao Y and Cheng T: Telomere dysfunction and cell cycle checkpoints in hematopoietic stem cell aging. Int $\mathrm{J}$ Hematol 94: 33-43, 2011. PMID: 21671044. DOI: 10.1007/ s12185-011-0882-z

23 Vitis MD, Berardinelli F and Sgura A: Telomere length maintenance in cancer: At the crossroad between telomerase and alternative lengthening of telomeres (ALT). Int J Mol Sci 19: 606, 2018. PMID: 29463031. DOI: 10.3390/ijms 19020606

24 Heidenreich B and Kumar R: TERT promoter mutations in telomere biology. Mutat Res 771: 15-31, 2017. PMID: 28342451. DOI: $10.1016 /$ j.mrrev.2016.11.002

25 Keohane EM: Introduction to hematologic neoplasms. In: Rodak's hematology-e-book. Clinical principles and applications. Keohane EM, Otto CN and Walenga JM (eds.). Saunders, 2019.

26 Harrison CJ: Cytogenetics of paediatric and adolescent acute lymphoblastic leukaemia. Br J Haematol 144: 147-156, 2009. PMID: 19006567. DOI: 10.1111/j.1365-2141.2008.07417.x

27 Ropio J, Merlio JP, Soares P and Chevret E: Telomerase activation in hematological malignancies. Genes 7: 61, 2016. PMID: 27618103. DOI: 10.3390/genes7090061

28 Beck RC, Kim AS, Goswami RS, Weinberg OK, Yeung CCS and Ewalt MD: Molecular/cytogenetic education for hematopathology fellows. Am J Clin Pathol 154: 149-177, 2020. PMID: 32444878. DOI: 10.1093/ajcp/aqaa038

29 Jebaraj BMC, Tausch E, Landau DA, Bahlo J, Robrecht S, TaylorWeiner AN, Bloehdorn J, Scheffold A, Mertens D, Böttcher S, Kneba M, Jäger U, Zenz T, Wenger MK, Fingerle-Rowson G, Wendtner C, Fink A-M, Wu CJ, Eichhorst B, Fischer K, Hallek M, Döhner $\mathrm{H}$ and Stilgenbauer S: Short telomeres are associated with inferior outcome, genomic complexity, and clonal evolution in chronic lymphocytic leukemia. Leukemia 33: 2183-2194, 2019. PMID: 30911113. DOI: 10.1038/s41375-019-0446-4

30 Norris K, Hillmen P, Rawstron A, Hills R, Baird DM, Fegan CD and Pepper C: Telomere length predicts for outcome to FCR chemotherapy in CLL. Leukemia 33: 1953-1963, 2019. PMID: 30700843. DOI: 10.1038/s41375-019-0389-9 
31 Warny M, Helby J, Sengeløv H, Nordestgaard BG, Birgens H and Bojesen SE: Bone marrow mononuclear cell telomere length in acute myeloid leukaemia and high-risk myelodysplastic syndrome. Eur J Haematol 102: 218-226, 2019. PMID: 30427547. DOI: 10.1111/ejh.13196

32 Bouillon A-S, Ferreira MSV, Awad SA, Richter J, Hochhaus A, Kunzmann V, Dengler J, Janssen J, Ossenkoppele G, Westerweel PE, Boekhorst PAWT, Mahon F-X, Hjorth-Hansen H, Isfort S, Fioretos T, Hummel S, Schemionek M, Wilop S, Koschmieder S, Saußele S, Mustjoki S, Beier F and Brümmendorf TH: Telomere shortening correlates with leukemic stem cell burden at diagnosis of chronic myeloid leukemia. Blood Adv 2: 15721579, 2018. PMID: 29980572. DOI: 10.1182/bloodadvances. 2018017772

33 Steinbrecher D, Jebaraj BMC, Schneider C, Edelmann J, Cymbalista F, Leblond V, Delmer A, Ibach S, Tausch E, Scheffold A, Bloehdorn J, Hallek M, Dreger P, Döhner H and Stilgenbauer $\mathrm{S}$ : Telomere length in poor-risk chronic lymphocytic leukemia: associations with disease characteristics and outcome. Leukemia Lymphoma 59: 1614-1623, 2017. PMID: 29063805. DOI: 10.1080/10428194.2017.1390236

34 Thomay K, Fedder C, Hofmann W, Kreipe H, Stadler M, Titgemeyer J, Zander I, Schlegelberger B and Göhring G: Telomere shortening, TP53 mutations and deletions in chronic lymphocytic leukemia result in increased chromosomal instability and breakpoint clustering in heterochromatic regions. Ann Hematol 96: 1493-1500, 2017. PMID: 28691153. DOI: 10.1007/s00277-017-3055-1

35 Williams J, Heppel NH, Britt-Compton B, Grimstead JW, Jones RE, Tauro S, Bowen DT, Knapper S, Groves M, Hills RK, Pepper C, Baird DM and Fegan C: Telomere length is an independent prognostic marker in MDS but not in de novo AML. Br J Haematol 178: 240-249, 2017. PMID: 28486748. DOI: 10.1111/bjh.14666

36 Park HS, Choi J, See C-J, Kim J-A, Park SN, Im K, Kim S-M, Lee DS and Hwang SM: Dysregulation of telomere lengths and telomerase activity in myelodysplastic syndrome. Ann Lab Med 37: 195, 2017. PMID: 28224765. DOI: 10.3343/alm. 2017.37.3.195

37 Watts JM, Dumitriu B, Hilden P, Kishtagari A, Rapaport F, Chen C, Ahn J, Devlin SM, Stein EM, Rampal R, Levine RL, Young $\mathrm{N}$ and Tallman MS: Telomere length and associations with somatic mutations and clinical outcomes in acute myeloid leukemia. Leukemia Res 49: 62-65, 2016. PMID: 27568819. DOI: $10.1016 /$ j.leukres.2016.07.013

38 Gerbing RB, Alonzo TA, Sung L, Gamis AS, Meshinchi S, Plon SE, Bertuch AA and Gramatges MM: Shorter remission telomere length predicts delayed neutrophil recovery after acute myeloid leukemia therapy: A report from the Children's Oncology Group. J Clin Oncol 34: 3766-3772, 2016. PMID: 27354474. DOI: 10.1200/JCO.2016.66.9622

39 Baljevic M, Dumitriu B, Lee J-W, Paietta EM, Wiernik PH, Racevskis J, Chen C, Stein EM, Gallagher RE, Rowe JM, Appelbaum FR, Powell BL, Larson RA, Coutré SE, Lancet J, Litzow MR, Luger SM, Young NS and Tallman MS: Telomere length recovery: a strong predictor of overall survival in acute promyelocytic leukemia. Acta Haematol 136: 210-218, 2016. PMID: 27632567. DOI: 10.1159/000448160

40 Sellmann L, Scholtysik R, Beer DD, Eisele L, Klein-Hitpass L, Nückel H, Dührsen U, Dürig J, Röth A and Baerlocher GM:
Shorter telomeres correlate with an increase in the number of uniparental disomies in patients with chronic lymphocytic leukemia. Leukemia Lymphoma 57: 590-595, 2015. PMID: 26457386. DOI: 10.3109/10428194.2015.1076929

41 Arons E, Zhou H, Edelman DC, Gomez A, Steinberg SM, Petersen D, Wang Y, Meltzer PS and Kreitman RJ: Impact of telomere length on survival in classic and variant hairy cell leukemia. Leukemia Res 39: 1360-1366, 2015. PMID: 26520623. DOI: 10.1016/j.leukres.2015.09.015

42 Lin TT, Norris K, Heppel NH, Pratt G, Allan JM, Allsup DJ, Bailey J, Cawkwell L, Hills R, Grimstead JW, Jones RE, BrittCompton B, Fegan C, Baird DM and Pepper C: Telomere dysfunction accurately predicts clinical outcome in chronic lymphocytic leukaemia, even in patients with early stage disease. Brit J Haematol 167: 214-223, 2014. PMID: 24990087. DOI: 10.1111/bjh. 13023

43 Jebaraj BMC, Kienle D, Lechel A, Mertens D, Heuberger M, Ott G, Rosenwald A, Barth TFE, Möller P, Zenz T, Döhner H and Stilgenbauer S: Telomere length in mantle cell lymphoma. Blood 121: 1184-1187, 2013. PMID: 23243283. DOI: 10.1182/ blood-2012-08-452649

44 Mansouri L, Grabowski P, Degerman S, Svenson U, Gunnarsson R, Cahill N, Smedby KE, Geisler C, Juliusson G, Roos G and Rosenquist R: Short telomere length is associated withNOTCH1/SF3B1/TP53aberrations and poor outcome in newly diagnosed chronic lymphocytic leukemia patients. Am J Hematol 88: 647-651, 2013. PMID: 23620080. DOI: 10.1002/ ajh.23466

45 Rampazzo E, Bonaldi L, Trentin L, Visco C, Keppel S, Giunco S, Frezzato F, Facco M, Novella E, Giaretta I, Bianco PD, Semenzato G and Rossi AD: Telomere length and telomerase levels delineate subgroups of B-cell chronic lymphocytic leukemia with different biological characteristics and clinical outcomes. Haematologica 97: 56-63, 2011. PMID: 21933855. DOI: 10.3324/haematol.2011.049874

46 Sellmann L, Beer DD, Bartels M, Opalka B, Nückel H, Dührsen U, Dürig J, Seifert M, Siemer D, Küppers R, Baerlocher GM and Röth A: Telomeres and prognosis in patients with chronic lymphocytic leukaemia. Int J Hematol 93: 74-82, 2011. PMID: 21203871. DOI: $10.1007 / \mathrm{s} 12185-010-0750-2$

47 Lin TT, Letsolo BT, Jones RE, Rowson J, Pratt G, Hewamana S, Fegan C, Pepper C and Baird DM: Telomere dysfunction and fusion during the progression of chronic lymphocytic leukemia: evidence for a telomere crisis. Blood 116: 1899-1907, 2010. PMID: 20538793. DOI: 10.1182/blood-2010-02-272104

48 Xian J, Obeng EO, Ratti S, Rusciano I, Marvi MV, Fazio A, Stefano AD, Mongiorgi S, Cappellini A, Ramazzotti G, Manzoli L, Cocco L and Follo MY: Nuclear inositides and inositidedependent signaling pathways in myelodysplastic syndromes. Cells 9: 697, 2020. PMID: 32178280. DOI: 10.3390/cells9030697

49 Schratz KE and Armanios M: Cancer and myeloid clonal evolution in the short telomere syndromes. Curr Opin Genet Dev 60: 112-118, 2020. PMID: 32276199. DOI: 10.1016/j.gde. 2020.02.019

50 Juliusson G and Hough R: Leukemia. Prog Tumor Res 43: 87100, 2016. PMID: 27595359. DOI: $10.1159 / 000447076$

51 Wang L, Xiao H, Zhang X, Wang C and Huang H: The role of telomeres and telomerase in hematologic malignancies and hematopoietic stem cell transplantation. J Hematol Oncol 7, 2014. PMID: 25139287. DOI: 10.1186/s13045-014-0061-9 
52 Jones $\mathrm{CH}$, Pepper $\mathrm{C}$ and Baird DM: Telomere dysfunction and its role in haematological cancer. Br J Haematol 156: 573-587, 2012. PMID: 22233151. DOI: 10.1111/j.1365-2141.2011. 09022.x

53 Olbertova H, Plevova K, Stranska K and Pospisilova S: Telomere dynamics in adult hematological malignancies. Biomed Pap Med Fac Univ Palacky Olomouc Czech Repub 163: 1-7, 2019. PMID: 30631211. DOI: 10.5507/bp.2018.084

54 Amini A, Ghaffari SH, Mortazai Y, Daliri K, Taranejoo S, Alimoghadam K and Ghavamzadeh A: Expression pattern of hTERT telomerase subunit gene in different stages of chronic myeloid leukemia. Mol Biol Rep 41: 5557-5561, 2014. PMID: 25015264. DOI: 10.1007/s11033-014-3472-3

55 Capraro V, Zane L, Poncet D, Perol D, Galia P, Preudhomme C, Bonnefoy-Berard N, Gilson E, Thomas X and El-Hamri M: Telomere deregulations possess cytogenetic, phenotype, and prognostic specificities in acute leukemias. Exp Hematol 39: 195-202, 2011. PMID: 21056083. DOI: 10.1016/j.exphem. 2010.10.008

56 Mohammadi K, Mehdi L, Mohammad RK: Blood parameters in treatment with arsenic trioxide in acute promyelocytic leukemia: A systematic review. Int J Hematol Oncol Stem Cell Res 14: 130-139, 2020. PMID: 32461798.

57 Martinelli S, Cuneo A and Rigolin GM: Identifying high-risk chronic lymphocytic leukemia: a pathogenesis-oriented appraisal of prognostic and predictive factors in patients treated with chemotherapy with or without immunotherapy. Mediterr J Hematol Infect Dis 8: 2016047, 2016. PMID: 27872727. DOI: 10.4084/mjhid.2016.047

58 Gramatges $\mathrm{MM}$ and Bertuch AA: Short telomeres: from dyskeratosis congenita to sporadic aplastic anemia and malignancy. Translat Res 162: 353-363, 2013. PMID: 23732052. DOI: $10.1016 /$ j.trs1.2013.05.003

59 Vose JM: Mantle cell lymphoma: 2017 update on diagnosis, riskstratification, and clinical management. Am J Hematol 92: 806813, 2017. PMID: 28699667. DOI: 10.1002/ajh.24797
60 Troussard X and Cornet E: Hairy cell leukemia 2018: Update on diagnosis, risk-stratification, and treatment. Am J Hematol 92: 1382-1390, 2017. PMID: 29110361. DOI: 10.1002/ajh.24936

61 Walsh SH, Grabowski P, Berglund M, Thunberg U, Thorsélius M, Tobin G, Åleskog A, Karlsson K, Sundström C, Laurell A, Enblad G, Rosenquist R and Roos G: Telomere length and correlation with histopathogenesis in B-cell leukemias/ lymphomas. Eur J Haematol 78: 283-289, 2007. PMID: 17286609. DOI: 10.1111/j.1600-0609.2007.00817.x

62 Ohyashiki K, Iwama H, Tauchi T, Shimamoto T, Hayashi S, Ando K, Kawakubo K and Ohyashiki JH: Telomere dynamics and genetic instability in disease progression of chronic myeloid leukemia. Leukemia Lymphoma 40: 49-56, 2000. PMID: 11426628. DOI: $10.3109 / 10428190009054880$

63 Caocci G, Greco M, Delogu G, Secchi C, Martino B, Labate C, Abruzzese E, Trawinska MM, Galimberti S, Orru F, Fozza C, Passerini CG, Galimi F and Nasa GL: Telomere length shortening is associated with treatment-free remission in chronic myeloid leukemia patients. J Hematol Oncol 9: 2016. PMID: 27473052. DOI: 10.1186/s13045-016-0293-y

64 Kishtagari A and Watts J: Biological and clinical implications of telomere dysfunction in myeloid malignancies. Ther Adv Hematol 8: 317-326, 2017. PMID: 29093807. DOI: 10.1177/ 2040620717731549

65 Rebechi MT and Pratz WK: Genomic instability is a principle pathologic feature of FLT3 ITD kinase activity in acute myeloid leukemia leading to clonal evolution and disease progression. Leukemia Lymphoma 58: 2040-2050, 2017. PMID: 28278729. DOI: $10.1080 / 10428194.2017 .128301$

Received July 27, 2020

Revised August 6, 2020

Accepted August 10, 2020 